\title{
Nowe metody audiometrii impedancyjnej. Część II. Szerokopasmowa tympanometria reflektancyjna
}

\section{New methods in acoustic immittance measurements. Part II. Wideband reflectance tympanometry}

\author{
Lech Śliwa ${ }^{1}$, Krzysztof Kochanek ${ }^{1,2}$ \\ ${ }^{1}$ Instytut Fizjologii i Patologii Słuchu, Światowe Centrum Słuchu, Warszawa/Kajetany \\ ${ }^{2}$ Uniwersytet Marii Curie-Skłodowskiej, Zakład Logopedii i Językoznawstwa Stosowanego, Lublin
}

Adres autora: Lech Śliwa, Światowe Centrum Słuchu, ul. Mokra 17, Kajetany, 05-830 Nadarzyn, e-mail: 1.sliwa@ifps.org.pl

\section{Streszczenie}

Metody badania właściwości mechanoakustycznych ucha środkowego wykorzystujące pomiar parametrów transmisyjnych fali akustycznej były znane od wielu lat i wykorzystywane w laboratoriach badawczych m.in. do modelowania struktury ucha. Metody te zyskały praktyczną przydatność $\mathrm{z}$ chwilą wdrożenia zautomatyzowanych, prostych w obsłudze systemów pomiarowych dostępnych dla lekarzy i audiologów.

Celem drugiej części pracy jest wprowadzenie do metod pomiarowych szerokopasmowej tympanometrii reflektancyjnej. Przedstawiono podstawy teoretyczne metody i zasady jej technicznej realizacji. Omówiono sens fizyczny i znaczenie wielkości mierzonych i ich związki z funkcjonowaniem ucha środkowego. Pokazano najważniejsze możliwości zastosowań metody w diagnostyce patologii ucha środkowego. Wybrane zagadnienia zilustrowano wynikami prac własnych autorów.

Omówiono także potencjalne ograniczenia metody i wskazano dziedziny, w których można oczekiwać intensywnych badań dla rozwoju diagnostyki otologicznej wykorzystującej metody tympanometrii szerokopasmowej.

Słowa kluczowe: tympanometria szerokopasmowa $\bullet$ reflektancja $\bullet$ absorbancja $\bullet$ patologia ucha środkowego $\bullet$ otoskleroza

\begin{abstract}
The methods of examination of the middle ear mechanoacoustic properties based on measurement of transmission parameters of acoustic wave have been known to researchers for several years and used, e.g., for modelling the middle ear structure. These methods have recently gained practical usefulness as soon as the automated, user-friendly wideband tympanometry systems became available for medical practitioners and audiologists.

The aim of the second part of the paper is to introduce the methods of the wideband reflectance tympanometry (WBT), and susbequently, the theoretical fundamentals and the technical principles regarding the implementation of the method. Furthermore, the physical meaning of the measurands, as well as their relationship with middle ear functioning will be elaborated. Furthermore, the most important possibilities of applying the WBT in the diagnostics of the middle ear pathologies will be shown. The selected problems will be illustrated with the results of the authors' own studies.
\end{abstract}

The potential limitations of the WBT method will also be presented, and the scientific disciplines expected to undertake indepth research and development activities for the WBT-based otologic diagnosis will be indicated.

Key words: wideband tympanometry $\bullet$ reflectance $\bullet$ absorbance $\bullet$ middle ear pathology $\bullet$ otosclerosis

\section{Wprowadzenie}

Tympanometria szerokopasmowa (ang. Wide-Band Tympanometry, WBT) rozwinęła się w ostatnich latach jako odpowiedź na niedostatki tympanometrii wieloczęstotliwościowej.
Jak wspomniano w pierwszej części artykułu [1], ta ostatnia góruje nad tympanometrią tradycyjną, niskoczęstotliwościową, dostarczając pełniejszych informacji o funkcjonowaniu ucha środkowego, dzięki możliwości analizy różnych składowych immitancji akustycznej dla różnych częstotliwości 
pomiarowych. Obok niewątpliwych zalet, metoda tympanometrii wielokomponentowej (wieloczęstotliwościowej) ma także ograniczenia, w tym między innymi:

1. Brak dobrze zdefiniowanych wzorców tympanogramów admitancji akustycznej i jej składowych $G_{\mathrm{a}}, B_{\mathrm{a}}$; dla różnych częstotliwości. Klasyfikacje wprowadzane przez różnych autorów (np. [2,3]) różnią się od siebie; wielowierzchołkowe tympanogramy susceptancji i konduktancji na wyższych częstotliwościach są często trudne do identyfikacji.

2. Kłopotliwy sposób wyznaczania parametrów charakterystycznych i duży rozrzut wartości normowych podawanych przez różnych autorów. Wartości parametrów normowych różnią się w zależności od warunków pomiaru tympanogramu, m.in. zakresu i kierunku zmian ciśnienia powietrza, sposobu wyznaczania susceptancji skompensowanej $B_{\mathrm{t}} \mathrm{i}$ admitancji statycznej $Y_{\mathrm{tm}}$ (ich wartości różnią się w zależności od tego, czy do oszacowania susceptancji przewodu słuchowego użyto wartości granicznej $B_{\mathrm{a}}$ dla dodatniego czy ujemnego krańca zakresu ciśnienia), a także metody pomiaru - czy pomiar był wykonywany przy stałej częstotliwości i zmiennym ciśnieniu, czy odwrotnie.

3. Błędy związane z pomiarem admitancji w zakresie większych częstotliwości, gdzie nie jest spełnione założenie o stałości ciśnienia akustycznego w przewodzie słuchowym - przy większych częstotliwościach zaznacza się wpływ efektu fali stojącej. Na skutek tego dokładność pomiaru składowych admitancji, $B_{\mathrm{t}} \mathrm{i} G_{\mathrm{t}}$, szybko maleje powyżej $f=$ ok. $1200 \mathrm{~Hz}$, pomiar powyżej ok. $1600 \mathrm{~Hz}$ jest uważany za niemiarodajny.

W tympanometrii reflektancyjnej przyjęto odmienną koncepcję pomiaru właściwości mechanoakustycznych ucha środkowego. Inaczej niż w niskoczęstotliwościowej tympanometrii klasycznej i tympanometrii wieloczęstotliwościowej, zasadniczymi wielkościami mierzonymi nie są ciśnienie akustyczne i prędkość akustyczna w przewodzie słuchowym zewnętrznym, lecz parametry falowe fal akustycznych rozchodzących się w przewodzie słuchowym. Ponadto, odmiennie niż w tympanometrii wieloczęstotliwościowej i klasycznej, typowym sygnałem pomiarowym jest nie ton, lecz impulsowy bodziec szerokopasmowy - trzask (ang. click) lub bodziec typu chirp (krótki ton z szerokopasmową modulacją częstotliwości). Parametry impedancyjne ucha środkowego mogą być wyznaczane drogą pośrednią, po odpowiedniej kalibracji źródła sygnału pomiarowego (sondy) i obliczeniu impedancji charakterystycznej przewodu słuchowego.

Celem tej części pracy jest wprowadzenie do metod pomiarowych i zastosowań szerokopasmowej tympanometrii reflektancyjnej. Biorąc za punkt wyjścia sens fizyczny wielkości mierzonych, pokazano ich związki $z$ funkcjonowaniem ucha środkowego. Pokazano także wybrane możliwości zastosowań metody w diagnostyce patologii ucha środkowego. Przedstawiono zasady technicznej realizacji tympanometrii szerokopasmowej i scharakteryzowano dostępne urządzenia pomiarowe. Do ilustracji omawianych zagadnień wykorzystano m.in. wyniki prac własnych autorów.

\section{Podstawy teoretyczne}

Przewód słuchowy zewnętrzny można traktować jak bezstratny falowód akustyczny, w którym rozchodzi się płaska fala akustyczna. Wielkościami charakteryzującymi przebieg drgań akustycznych, w określonym punkcie przewodu, są ciśnienie akustyczne $-p_{a}(t)$ oraz prędkość akustyczna (przepływ akustyczny) $-u(t)=A v(t)$, gdzie $v(t)$ oznacza wartość chwilową prędkości drgań cząsteczek ośrodka (powietrza), a $A$ jest polem przekroju przewodu. Przyjmuje się, że dźwięk w przewodzie jest tonem sinusoidalnym, tzn. $p_{\mathrm{a}}(t)$ i $u(t)$ są funkcjami sinusoidalnie zmiennymi o amplitudach (odpowiednio) $P_{\mathrm{am}}$ i $U_{\mathrm{m}}$.

Gdy kanał ma (hipotetycznie) nieograniczoną długość lub gdy energia fali akustycznej jest całkowicie pochłaniana przez pewien element na końcu kanału, mamy do czynienia z tzw. falowodem bezodbiciowym. Stosunek ciśnienia akustycznego i prędkości akustycznej jest wówczas stały w każdym punkcie falowodu i w każdej chwili czasu:

$$
\left.\frac{p_{a}(t)}{u(t)}\right|_{u(t) \neq 0}=\frac{P_{a m}}{U_{m}}=Z_{c}=\frac{\rho \cdot c}{A}
$$

Wielkość $Z_{\mathrm{c}}$ jest tzw. impedancją charakterystyczną falowodu (kanału), $\rho$ - jest gęstością ośrodka (masą właściwą powietrza), a $c$ - prędkością dźwięku. Analogicznie, $Y_{c}=Z_{c}^{-1}$ jest nazywana admitancją charakterystyczną.

Przykładowo, dla przewodu słuchowego zewnętrznego osoby dorosłej można przyjąć [4]: $A=0,43 \mathrm{~cm}^{2}$, a ponieważ $\rho=0,00122 \mathrm{~g} / \mathrm{cm}^{3}, c=33500 \mathrm{~cm} / \mathrm{s}$, stąd $Z_{c}=95,2 \mathrm{~g} / \mathrm{cm}^{4} \mathrm{~s}=95,2 \Omega_{\mathrm{ak}}$ (ohm), oraz $Y_{\mathrm{c}}=1 / Z_{\mathrm{c}}=0,0105 \Omega_{\mathrm{ak}}{ }^{-1}=10,5 \mathrm{mmho}$. Przewód słuchowy osób dorosłych może różnić się długością i średnicą, toteż różni autorzy podają oszacowania wartości impedancji charakterystycznej $Z_{\mathrm{c}}$ w przedziale $60 \ldots 95 \mathrm{ohm}$.

Fala akustyczna biegnąca $\mathrm{w}$ falowodzie przenosi, w odcinku czasu $\Delta t$, energię $E_{\mathrm{a}}$, którą można wyrazić wzorem:

$$
E_{a}=\frac{P_{a}^{2}}{Z_{c}} \Delta t
$$

gdzie $P_{\mathrm{a}}$ jest wartością skuteczną ciśnienia akustycznego.

Gdy falowód dźwiękowy (np. przewód słuchowy zewnętrzny) jest zakończony pewną strukturą, której impedancja akustyczna, $Z_{\mathrm{a}}$, różni się od $Z_{\mathrm{c}}$, wówczas część energii fali akustycznej zostaje pochłonięta przez tę strukturę, a część powraca w formie fali odbitej, biegnącej w kierunku źródła. W przewodzie słuchowym występują wówczas dwie fale: padająca, biegnąca od źródła do błony bębenkowej, oraz odbita, biegnąca w kierunku przeciwnym, których ciśnienia akustyczne wynoszą odpowiednio $P_{\mathrm{i}}$, i $P_{\mathrm{r}}$ (rycina 1).

Współczynnik odbicia, $R$, jest stosunkiem ciśnienia akustycznego fali odbitej do ciśnienia fali padającej:

$$
R=\frac{P_{r}}{P_{i}}
$$

gdzie $P_{\mathrm{r}} P_{\mathrm{i}}$ oznaczają odpowiednio amplitudy zespolone ciśnienia akustycznego fali odbitej i fali padającej (patrz [1], Dodatek 1).Wartość współczynnika odbicia zależy od stosunku impedancji obciążenia, $Z_{\mathrm{a}}$, do impedancji charakterystycznej, $Z_{\mathrm{c}}$ :

$$
R=\frac{Z_{a}-Z_{c}}{Z_{a}+Z_{c}}=\frac{Y_{c}-Y_{a}}{Y_{a}+Y_{c}}
$$




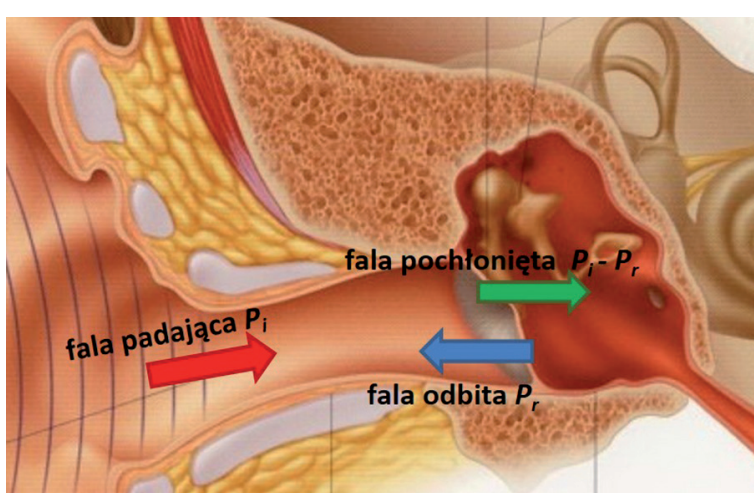

Rycina 1. Schemat poglądowy zjawiska odbicia dźwięku w przewodzie słuchowym

Figure 1. Illustrative scheme of the sound reflection effect in the ear canal

Jak widać ze wzoru (4), w ogólnym przypadku współczynnik odbicia jest - podobnie jak impedancja - liczbą zespoloną, która zależy od częstotliwości, $R(\mathrm{j} \omega)$. Moduł współczynnika odbicia $|R|$ określa stosunek amplitud (lub wartości skutecznych) fali odbitej i padającej, a argument przesunięcie fazy między falą padającą i odbitą (rycina 2).

Fale padająca i odbita niosą określone energie; w odcinku czasu $\Delta t$ energie te, zgodnie ze wzorem (2), są równe $E_{\mathrm{ai}}=P_{\mathrm{i}}^{2} \cdot \Delta t / Z_{\mathrm{c}}$ oraz $E_{\mathrm{ar}}=P_{\mathrm{r}}^{2} \cdot \Delta t / Z_{\mathrm{c}}$, gdzie $P_{\mathrm{i}}^{2}$ i $P_{\mathrm{r}}^{2}$ oznaczają, odpowiednio, kwadraty wartości skutecznych ciśnienia akustycznego fali padającej i odbitej.

Współczynnikiem odbicia mocy (lub energii), ER, nazywa się stosunek mocy fali odbitej do mocy fali padaja cej, równy oczywiście stosunkowi energii tych fal; zgodnie z (2) mamy:

$$
E R=\frac{P_{r}^{2}}{P_{i}^{2}}
$$

Iloraz kwadratów wartości skutecznych fal odbitej i padającej można, zgodnie ze wzorem (4), wyrazić jako:

$$
E R=|R|^{2}=\left|\frac{Z_{a}-Z_{c}}{Z_{a}+Z_{c}}\right|^{2}=\left|\frac{Y_{c}-Y_{a}}{Y_{a}+Y_{c}}\right|^{2}
$$

Współczynnik odbicia mocy, nazywany także reflektancją (ang. Energy Reflectance, ER, lub Power Reflectance) ma więc bezpośredni związek z impedancją (lub admitancją) zamykającą falowód akustyczny - w przypadku ucha jest to impedancja ucha środkowego, $Z$, zamykająca przewód słuchowy zewnętrzny.

\section{Metodyka pomiaru parametrów odbiciowych fali akustycznej}

Zgodnie z tym, co przedstawiono powyżej, gdy w przewodzie słuchowym zewnętrznym generowane są drgania dźwiękowe (np. przez przetwornik elektroakustyczny sondy pomiarowej), mamy tam do czynienia $\mathrm{z}$ dwiema falami akustycznymi: falą padającą, biegnącą w kierunku ucha środkowego i falą odbitą od niego.

Współczynnik odbicia mocy, reflektancja (5), charakteryzuje ilość mocy odbitej od błony bębenkowej i pozostałych struktur ucha środkowego. Przyjmuje on wartości w przedziale od 0 do jedności, przy czym $E R=1$ oznacza całkowite odbicie mocy. Jej dopełnieniem do jedności jest $\boldsymbol{a} \boldsymbol{b}$ sorbancja (ang. Energy Absorbance, EA)

$$
E A=1-E R
$$

która określa udział energii fali akustycznej pochłoniętej przez ucho środkowe. Tak więc, wartość $E A=1$ oznacza, że cała energia fali akustycznej została pochłonięta przez ucho środkowe. Absorbancja jest niekiedy wyrażana w mierze logarytmicznej; wartość ta bywa nazywana
A

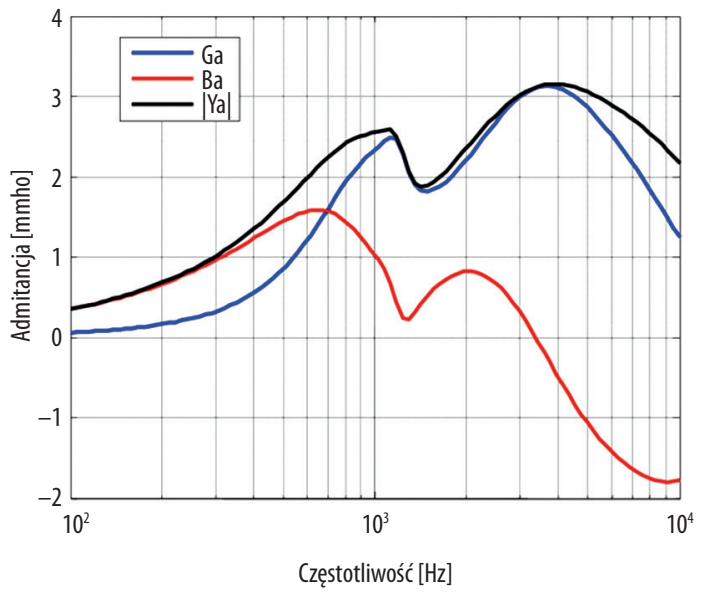

B

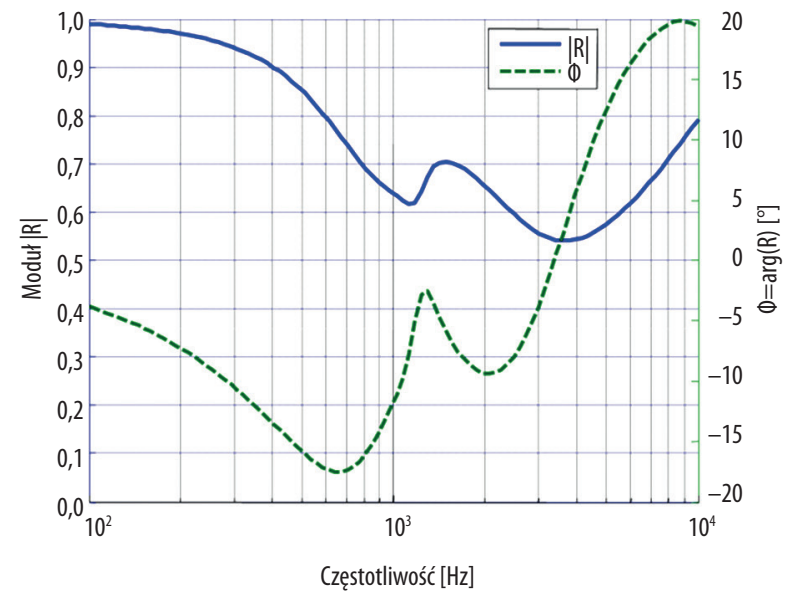

Rycina 2. (A) Admitancja ucha środkowego: przebiegi konduktancji, $G_{a}$, susceptancji, $B_{a}$, i modułu admitancji $\left|Y_{a}\right|$ w funkcji częstotliwości. (B) Zespolony współczynnik odbicia, $R(\mathrm{j} \omega)$ : funkcje częstotliwościowe modułu $|R|$ i argumentu $\Phi$. Zależności obliczone na podstawie modelu ucha środkowego Zwisłockiego [22] i Kinglebotna [23]

Figure 2. (A) Admittance of middle ear: courses of conductance, $G_{a}$, susceptance, $B_{a}$, and admittance modulus $\left|Y_{a}\right|$ versus frequency; (B) Complex reflection coefficient, $R(\mathrm{j} \omega)$ : frequency functions of modulus, $|R|$, and argument, $\Phi$. The functions calculated based on the Zwislocki's middle ear model [22] with the data collected by Kinglebotn [23] 
transmitancja (ang. Acoustic Transfer Function, ATF, lub Energy Transmittance, ET) ${ }^{1}$ :

$$
A T F=10 \log (1-E R) \quad[\mathrm{dB}]
$$

AFT oznacza względny poziom mocy transmitowanej do ucha środkowego odniesiony do mocy padającej fali akustycznej; wartości AFT zmieniają się od $0 \mathrm{~dB}$ (cała moc przetransmitowana do ucha środkowego) do $-\infty$ (cała moc odbita).

Metodyka pomiaru parametrów odbiciowych jest, w ogólnym zarysie, następująca. Bodźce są podawane przez sondę pomiarową, zawierającą przetwornik elektroakustyczny (miniaturową słuchawkę) i mikrofon, podobnie jak w klasycznej tympanometrii. Poziom bodźców jest zbliżony do tego, jaki stosuje się w badaniach otoemisji akustycznych (ok. 70-80 dB HL). Źródło sygnału (przetwornik elektroakustyczny sondy pomiarowej) jest kalibrowane metodą pomiaru ciśnienia akustycznego w obciążeniu o znanej impedancji akustycznej (wnęka pomiarowa). Na tej podstawie wyznacza się akustyczną impedancję wewnętrzną źródła sygnału, $Z_{\mathrm{s}}$, i wewnętrzne ciśnienie akustyczne źró$\mathrm{d} ł a, P_{\mathrm{s}}$, (obydwa parametry są wielkościami zespolonymi zależnymi od częstotliwości) ${ }^{2}$. Jeśli jest znana impedancja charakterystyczna przewodu słuchowego, $Z_{c}$, to ciśnienie akustyczne fali padającej można wyliczyć ze wzoru (9), który wyraża znaną z elektrotechniki zasadę „dzielnika impedancyjnego" [4-6].

$$
P_{i}=P_{s} \frac{Z_{c}}{Z_{c}+Z_{s}}=P_{s} \frac{Y_{s}}{Y_{c}+Y_{s}}
$$

Wartość impedancji charakterystycznej $Z_{c}$ można znaleźć, korzystając ze wzoru (1), gdy znamy pole przekroju przewodu słuchowego i pozostałe parametry fizyczne (odpowiednie obliczenia mogą być wykonywane przez oprogramowanie urządzenia pomiarowego, do którego wprowadza się informację o średnicy przewodu). Wypadkowe ciśnienie akustyczne w przewodzie słuchowym, $P_{\mathrm{m}}$, mierzone przez mikrofon sondy pomiarowej jest sumą ciśnień dwu fal - padającej, $P_{\mathrm{i}}$, i odbitej $P_{\mathrm{r}}$;

$$
P_{m}=P_{i}+P_{r}
$$

gdy znana jest ta pierwsza (9), można wyliczyć ciśnienie akustyczne fali odbitej. Można również obliczyć impedancję (lub admitancję) widzianą w płaszczyźnie końcówki sondy pomiarowej, $Z_{\mathrm{m}},[4,6]$.

$$
Y_{m}=\frac{U_{s}}{P_{m}}-Y_{s}
$$

Admitancja $Y_{\mathrm{m}}$ różni się od admitancji elementu zamykającego przewód słuchowy, $Y_{\mathrm{t}}$, (tzn. admitancji ucha środkowego widzianej w płaszczyźnie błony bębenkowej). Różnica między impedancjami wynika z faktu, że amplituda i faza ciśnienia akustycznego (i prędkości akustycznej) w płaszczyźnie końcówki sondy pomiarowej są różne od tych, jakie występują na obciążeniu (w płaszczyźnie błony bębenkowej), ponieważ odcinek fali akustycznej między tymi punktami ma skończoną długość. Różnicę tę można uwzględnić i wyliczyć wartość $Y_{\text {t }}$, gdy znana jest długość akustyczna przewodu słuchowego, $L$. Niestety, bezpośredni pomiar tej długości jest trudny i można ją jedynie oszacować z mniejszym lub większym błędem (przyjmuje się $L \approx 1 \div 1,5 \mathrm{~cm}[4])$. Niemniej, ze wzorów (9-11) można poprawnie wyliczyć moduł współczynnika odbicia $|R|$. Zgodnie ze wzorem (4) wartość współczynnika odbicia w płaszczyźnie sondy wynosi:

$$
R_{m}=\frac{Y_{c}-Y_{m}}{Y_{c}+Y_{m}}
$$

Ponieważ zakłada się, że przewód słuchowy zewnętrzny jest jednorodnym, bezstratnym falowodem akustycznym (o stałej, rzeczywistej impedancji charakterystycznej), wartość modułu współczynnika odbicia jest stała na całej jego długości.

$$
\left|R_{m}\right|=|R|=\text { const. }
$$

Można więc na podstawie (6), (12) wyliczyć parametry określające transmisję mocy do ucha środkowego: $E R=|R|^{2}$, $E A=1|R|^{2}$ itd. Widać stąd istotną przewagę metody pomiaru parametrów reflektancyjnych nad konwencjonalną metodą pomiaru admitancji akustycznej, na wynik pomiaru której znacząco wpływała odległość sondy pomiarowej od granicy ucha środkowego.

We współczesnych systemach pomiarowych wykorzystuje się z reguły szerokopasmowe bodźce dźwiękowe: krótkie impulsy (trzask) lub szerokopasmowe bodźce tonalne z modulacją częstotliwości (chirp). Analiza sygnałów jest przeprowadzana w dziedzinie widmowej. Bodźce szerokopasmowe, stosowne $\mathrm{w}$ opisanej metodzie pomiarowej, można w dziedzinie widma traktować jak zbiór wielu składowych sinusoidalnych o (prawie) jednakowych amplitudach i częstotliwościach przybierających (teoretycznie) wszystkie możliwe wartości w pewnym przedziale. Odpowiedź układu jest w dziedzinie widmowej zbiorem odpowiedzi sinusoidalnych na kolejne sinusoidalne składowe bodźca. Tak więc, analizując widmo odpowiedzi, uzyskujemy całą charakterystykę częstotliwościową układu, np. zależność częstotliwościową współczynnika odbicia $R(j \omega)$ w zadanym paśmie częstotliwości. W praktyce analiza jest przeprowadzana na podstawie widma dyskretnego, tzn. w wyniku cyfrowego przetwarzania sygnałów wyznaczane są odpowiedzi dla $n$ różnych częstotliwości mamy do dyspozycji $n$ składowych widma bodźca (typowo $\mathrm{n}=100 \div 200)$ w przedziale - typowo - od ok. $200 \mathrm{~Hz}$ do $6-8 \mathrm{kHz}$ i tyleż wartości mierzonego parametru, np. $|R|^{2}$, dla odpowiednich częstotliwości.

\footnotetext{
1. Zgodnie z konsensusem przyjętym przez komitet ekspertów w roku 2013 [7] zalecono stosowanie ogólnej nazwy szerokopasmowa immitancja akustyczna (ang. Wideband Acoustic Immittance, WAI) na określenie miar szerokopasmowych zarówno impedancyjnych, takich jak impedancja i admitancja, jak i reflektancyjnych (związanych z odbiciem mocy), takich jak reflektancja i absorbancja. Zalecono, by zaniechać stosowania terminu 'transmitancja', lecz używać nazwy absorbancja, gdy wielkość ta jest wyrażona w wartościach liczbowych, od 0 do 1, lub poziom absorbancji, gdy jest wyrażona w skali decybelowej (por. [8]).

2. Źródło sygnału akustycznego jest reprezentowane przez schemat zastępczy Thévenina [6], w postaci wewnętrznego generatora ciśnienia o wydajności $P_{s}$ i szeregowej impedancji $Z_{s}$, lub schemat Nortona będący połączeniem wewnętrznego generatora prędkości akustycznej o wydajności $U_{s} \mathrm{i}$ równoległej admitancji $Y_{s}$; obydwa schematy są równoważne, gdyż $U_{s}=P / Z_{s}, Y_{s}=1 / Z_{s}$.
} 


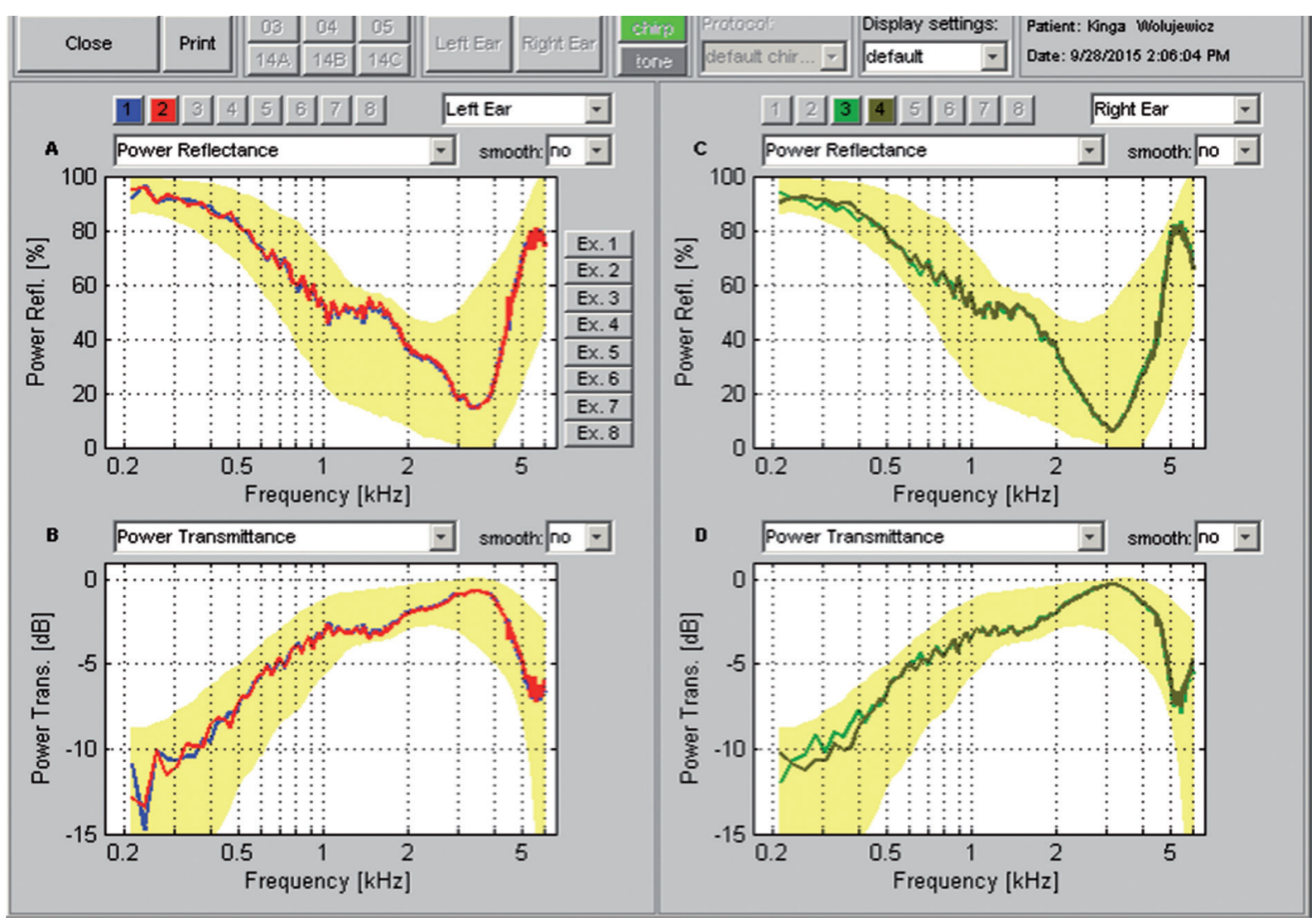

Rycina 3. Przykładowe charakterystyki częstotliwościowe reflektancji i poziomu absorbancji dla ucha normalnego (ekran systemu pomiarowego Mimosa Acoustics HearlD). Zaznaczono pole wartości normowych (dane z badań własnych [33])

Figure 3. Sample frequency characteristics of the reflectance and the absorbance levels for normal ear (a screenshot from the Mimosa Acoustics HearlD). The measurement system field of the normative values are marked (data from the authors' own rese$\operatorname{arch~[33])~}$

\section{Użyteczność diagnostyczna tympanometrii reflektancyjnej}

Typowy wynik pomiaru, przebiegi reflektancji i poziomu absorbancji w funkcji częstotliwości, jest przedstawiony na rycinie 3 .

Pomiar tych parametrów może być, w stosunku do klasycznych pomiarów immitancji, dobrą alternatywną metodą badania właściwości mechanoakustycznych ucha środkowego.

1. Wynik pomiaru parametrów transmisyjnych (ER, ET, $A T F)$ jest mało wrażliwy na położenie sondy - teoretycznie ich wartości nie zależą w ogóle od długości przewodu słuchowego, jeśli założyć, że ma on właściwości bezstratnego falowodu.

2. Parametry odbiciowe można mierzyć w szerokim zakresie częstotliwości (praktycznie $226 \mathrm{~Hz}-8 \mathrm{kHz}$ ), a więc można badać właściwości ucha środkowego w zakresie powyżej $1 \mathrm{kHz}$, gdzie bezpośredni pomiar immitancji jest niepewny, niedokładny lub niemożliwy.

3. Pomiar absorbancji (lub reflektancji) może być wykonany jednocześnie $\mathrm{w}$ szerokim paśmie częstotliwości i przy zmiennym ciśnieniu powietrza w przewodzie słuchowym; uzyskuje się w ten sposób bogate źródło informacji o stanie ucha środkowego, co pozwala na dokładniejsze wykrywanie i różnicowanie patologii, zarówno w populacji osób dorosłych, jak i dzieci.
4. Wartości parametrów odbiciowych (np. absorbancji) są miarą energii fali dźwiękowej zaabsorbowanej przez struktury ucha środkowego, a więc mają związek z energią docierającą do ślimaka - w pośredni sposób także z czułością słuchu. Podejmowane są próby oceny, na podstawie parametrów reflektancyjnych, przewodzeniowego ubytku słuchu $[8,9]$ - co nie było osiągalne w klasycznej tympanometrii.

Wartość reflektancji silnie zależy od częstotliwości (por. rycina 3): jest ona bliska jedności dla małych częstotliwości (gdy moduł admitancji ucha środkowego jest mały) i osiąga minimum dla częstotliwości średnich, dla uszu normalnych $1000-4000 \mathrm{~Hz}$ (w okolicy rezonansu struktury ucha środkowego). Ponownie wzrasta dla dużych częstotliwości (gdy rośnie składowa bezwładnościowa impedancji, wskutek czego admitancja ucha maleje). Na rycinie $4 \mathrm{~A}$ przedstawiono wyznaczoną pomiarowo zależność częstotliwościową reflektancji ucha środkowego dla osób dorosłych, otologicznie normalnych (uśrednione dane dla różnych populacji kobiet i mężczyzn, wg [10], oraz na rycinie $4 \mathrm{~B}$ przykładowe wyniki pomiaru absorbancji w grupie osób młodych, normalne słyszących [11]. Jak widać, wartości indywidualne wykazują dość znaczny rozrzut wokół wartości normowych, niemniej, w przypadku patologii występują wyraźnie charakterystyczne zmiany przebiegu tych zależności, które dają możliwość identyfikacji rodzaju patologii, co będzie przedstawione w dalszej części pracy. 
A

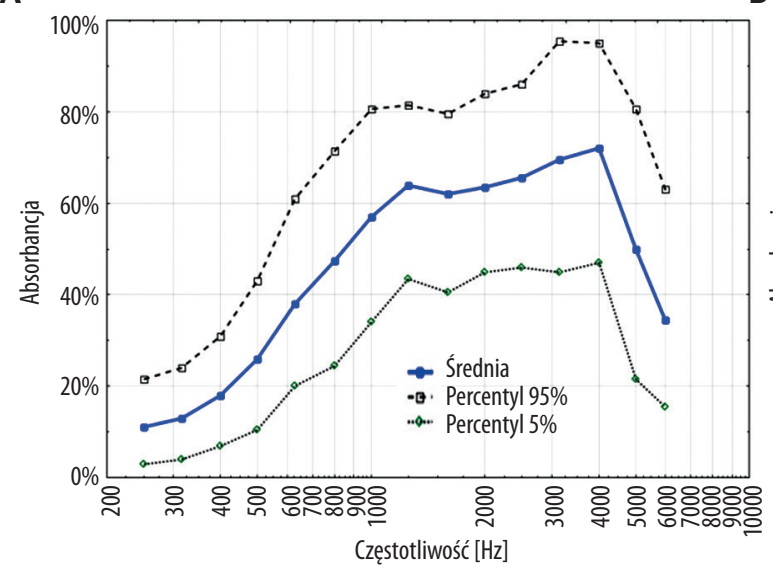

B

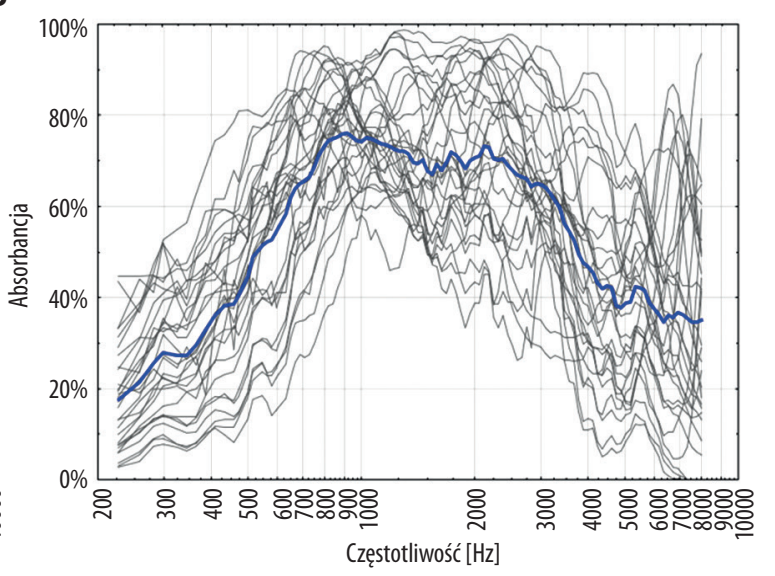

Rycina 4. (A) Wartości normowe i zakres rozrzutu (percentyle 5\% i 95\%) wartości absorbancji dla otologicznie normalnych osób dorosłych, wg uśrednionych danych z różnych ośrodków [10]; (B) Zależności częstotliwościowe absorbancji: wyniki indywidualne i wartość średnia w grupie osób normalnie słyszących [11]

Figure 4. (A) The mean values and the percentile range (5\% and $95 \%$ ) of the absorbance for otologically-normal adults, based on averaged data from different centres (according to [10]); (B) The absorbance frequency functions: the characteristics of individual patients and mean value in a group of the normal-hearing subjects [11]

Wpływ niektórych czynników patologicznych na przebieg reflektancji (absorbancji) można scharakteryzować następująco [12-15]:

1.Perforacja błony bębenkowej. W przebiegu reflektancji uszkodzenie to objawia się wyraźnym przesunięciem minimum w kierunku małych częstotliwości (poniżej $1000 \mathrm{~Hz}$ ). Wynika to stąd, że otwór (nawet o małych rozmiarach) wprowadza składową bezwładnościową (ujemną) susceptancji w zakresie częstotliwości, gdzie w uchu normalnym dominuje składowa sprężysta (dodatnia). W wyniku tego maleje częstotliwość rezonansowa struktur ucha - a przy tej częstotliwości reflektancja osiąga minimum. W zakresie wyższych częstotliwości (powyżej $3000 \mathrm{~Hz}$ ) kształt przebiegu reflektancji jest podobny jak w uszach normalnych, lecz przyjmuje ona mniejsze wartości. Wynik pomiaru reflektancji może być bardzo czułym wskaźnikiem istnienia perforacji $[16,17]$.

2. Tympanoskleroza. Patologiczne usztywnienie błony bębenkowej zmniejsza jej susceptancję (zwiększa reaktancję) sprężystą, co powoduje wzrost impedancji ucha środkowego w zakresie małych i średnich częstotliwości. Efektem jest wzrost reflektancji w tym zakresie w porównaniu z wartościami dla uszu normalnych. Objawy tympanosklerozy są również zauważalne w konwencjonalnej tympanometrii $226 \mathrm{~Hz}$, lecz nie zawsze jednoznacznie rozpoznane (tympanogramy mogą być „na granicy normy"). Zastosowanie pomiaru reflektancji jako badania dodatkowego, obok tympanometrii $226 \mathrm{~Hz}$, zwiększa czułość testu przy wykrywaniu tympanosklerozy praktycznie do $100 \%[15,18]$.

3. Zmiany ciśnienia $w$ jamie ucha środkowego. Różnica między ciśnieniem w jamie bębenkowej ucha środkowego i ciśnieniem otoczenia powoduje usztywnienie błony bębenkowej, wzrost impedancji ucha środkowego, w efekcie czego rośnie reflektancja w całym zakresie częstotliwości, przy czym relatywnie największy wzrost obserwuje się dla małych częstotliwości (por. rycina 5 - krzywa ciemnoniebieska). Niektórzy badacze [14,19] sugerują, że ujemna różnica ciśnień (obniżenie ciśnienia w uchu środkowym) mniej wpływa na reflektancję niż podobna różnica dodatnia, zwłaszcza dla średnich częstotliwości (1-3 kHz), lecz różnice są mało znaczące.

4. Płyn w jamie ucha środkowego. Jama ucha środkowego jest normalnie wypełniona powietrzem, które jest ośrodkiem sprężystym (podatnym). Całkowite wypełnienie jamy nieściśliwym płynem (lub tkanką, która narasta $\mathrm{w}$ stanach patologicznych) powoduje gwałtowny wzrost impedancji akustycznej tej struktury, a to oznacza wzrost reflektancji do wartości bliskich jedności w całym zakresie częstotliwości. Przy częściowym wypełnieniu zmiany reflektancji są mniejsze, dotyczą zakresu małych częstotliwości i stają się bardzo wyraźne, gdy płyn zajmuje ponad 50\% objętości ucha środkowego $[14,19]$. Gdy wypełnienie płynem jest całkowite, bliskie $100 \%$, pojawia się pewien charakterystyczny objaw - ostre minimum reflektancji w zakresie wysokich częstotliwości (por. rycina 5 - krzywa czerwona). Wytłumaczeniem tego zjawiska może być fakt, że pęcherzyki powietrza zawieszone w płynie działają jak rezonatory, których częstotliwość rezonansowa leży w zakresie dużych częstotliwości.

5. Usztywnienie łańcucha kosteczek (otoskleroza). Charakterystycznym objawem tej patologii jest wyraźny wzrost reflektancji (spadek absorbancji) w zakresie częstotliwości poniżej $1 \mathrm{kHz}[11,14,19-21]$ powodowany generalnie wzrostem reaktancji sprężystej struktur ucha środkowego, co przekłada się na wzrost impedancji i częstotliwości rezonansowej tego układu (por. rycina 5 - krzywa niebieska). Minimum reflektancji (maksimum absorbancji) występuje w zakresie częstotliwości ok. $3 \mathrm{kHz}$, wyższych niż dla uszu normalnych, gdzie wartości ekstremalne obserwuje się w okolicy 1-2 kHz.

6. Nieciagłość łańcucha kosteczek. Przerwanie łańcucha kosteczek w dowolnym miejscu prowadzi do radykalnego zmniejszenia reaktancji sprężystej (zwiększenia susceptancji) ucha środkowego i obniżenia częstotliwości rezonansowej. Efektem jest bardzo wyraźne wcięcie w przebiegu reflektancji pojawiające się w okolicy 400-800 Hz [14,15]. 


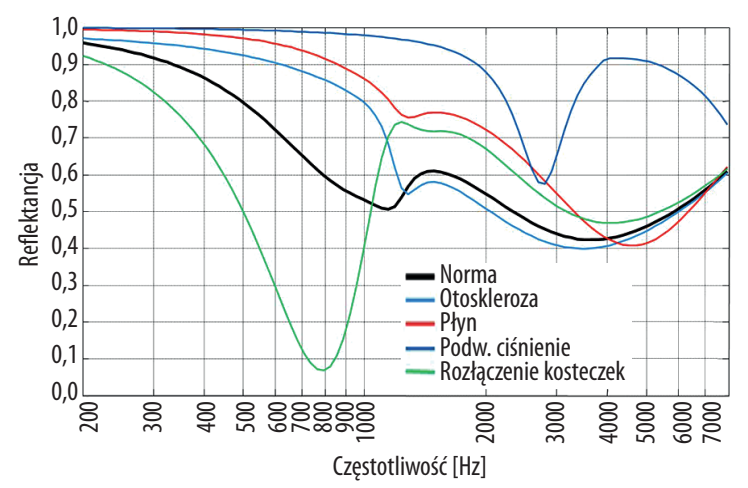

Rycina 5. Szkic ilustrujący zależności częstotliwościowe reflektancji w przypadkach różnych patologii ucha środkowego. Przebiegi obliczone na podstawie modelu ucha środkowego $[19,22,23]$

Figure 5. The outline of courses of reflectance frequency functions in cases of different middle ear pathologies, calculated on the basis of the theoretical model of the middle ear $[19,22,23]$

Objaw ten jest bardzo charakterystyczny (por. rycina 5 krzywa zielona) i wyraźnie odróżnia uszy z nieciągłością łańcucha kosteczek od uszu normalnych.

Na rycinie 5 przedstawiono szkic ilustrujący charakterystyczne zmiany przebiegu funkcji częstotliwościowej reflektancji powodowane różnymi patologiami. Zależności zostały wyznaczone obliczeniowo na podstawie modelu struktury ucha środkowego zaproponowanego oryginalnie przez Zwisłockiego [22], w którym wartości elementów schematu zastępczego dla ucha normalnego i patologii przyjęto wg prac Kringlebotna [23] i Voss [19]. Uzyskane tą drogą przebiegi teoretyczne dobrze ilustrują jakościowy charakter zmian patologicznych w uchu środkowym i są bliskie rzeczywistym wynikom otrzymanym z pomiarów reflektancji u osób otologicznie normalnych i pacjentów z patologiami ucha środkowego [19].

\section{Tympanogramy reflektancyjne - relacje między tympanometrią reflektancyjną i klasyczną}

Jak wspomniano wyżej, pomiar absorbancji (lub reflektancji) może być wykonany w szerokim paśmie częstotliwości. Ponadto, ciśnienie powietrza w przewodzie słuchowym może być zmieniane w trakcie pomiaru w sposób skokowy lub ciągły. Można więc przeprowadzić serię pomiarów przy ustalonych częstotliwościach i zmieniających się ciśnieniach albo dla ustalonego ciśnienia wykonać pomiary przy różnych częstotliwościach [24]. W praktyce, w dostępnych systemach pomiarowych, parametry odbiciowe są mierzone najczęściej przy użyciu bodźca szerokopasmowego (a więc wyznaczane w szerokim przedziale częstotliwości) przy wolno zmieniającym się ciśnieniu w przewodzie słuchowym zewnętrznym [25]. Zakres, kierunek i szybkość zmian ciśnienia mają pewien wpływ na wynik pomiaru, niemniej, przy odpowiednio dobranych parametrach (względnie powolnych zmianach ciśnienia) można zapewnić wystarczającą dokładność pomiaru. Uzyskuje się tą drogą, w wyniku jednego krótkotrwałego pomiaru, bogate źródło informacji o stanie ucha środkowego.

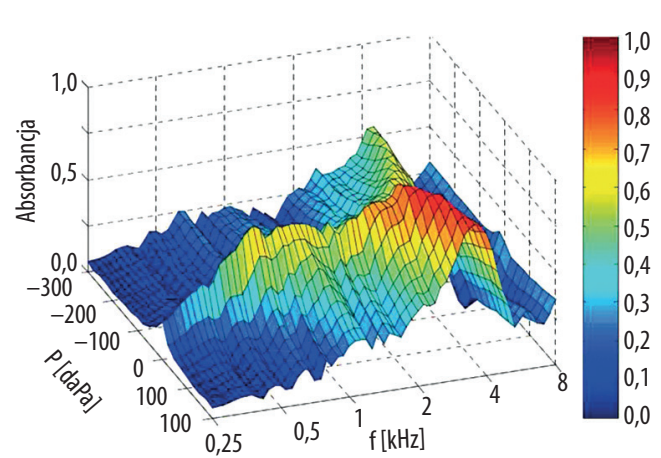

Rycina 6. Typowa zależność absorbancji w funkcji częstotliwości i ciśnienia w przewodzie słuchowym zewnętrznym dla ucha normalnego (dane z badań własnych [11])

Figure 6. Typical dependence of the absorbance on the frequency and the air pressure in the ear canal for a normal-hearing subject (data from the authors' own research [10])

Typowym wynikiem takiego pomiaru jest funkcja dwu zmiennych, obrazująca zależność reflektancji (bądź absorbancji) od ciśnienia powietrza w przewodzie słuchowym zewnętrznym i częstotliwości (rycina 6). Zależność ta jest najczęściej przedstawiana w postaci wykresu trójwymiarowego ze zmienną zależną (wartością absorbancji) wyrażoną w skali barw.

Przekrój tej funkcji wzdłuż osi „f" obrazuje zależność absorbancji od częstotliwości przy stałym ciśnieniu, $\left.E A(f)\right|_{\mathrm{P}=\text { const }}$. W zastosowaniach praktycznych interesujące są np. charakterystyki absorbancji dla ciśnienia szczytowego $(P=T P)$ - por. rycina $7 \mathrm{~B}$ - lub dla ciśnienia otoczenia $(P=0)$. Z kolei, przekroje wzdłuż osi „P” oznaczają zależność absorbancji od ciśnienia przy stałej częstotliwości, $\left.E A(P)\right|_{f=\text { const. }}$. Charakterystyki takie wyznacza się m.in. dla typowych częstotliwości tympanometrycznych (226 Hz, $1000 \mathrm{~Hz}$ itp.) - por. rycina 7A. Przykłady charakterystyk absorbancji w funkcji ciśnienia i częstotliwości dla ucha osoby normalnie słyszącej przedstawiono na rycinie 7. Jak widać, funkcja $E A(P)$ ma kształt podobny do „klasycznego” tympanogramu dla małych częstotliwości - lecz należy pamiętać, że przedstawia przebieg innej wielkości. Można także wyznaczać uśrednione „tympanogramy absorbancyjne” (zależność absorbancji uśrednionej w pewnym przedziale częstotliwości, np. 800-2000 Hz lub 375-2000 kHz, od ciśnienia w przewodzie słuchowym). Doniesienia różnych autorów wskazują, że charakterystyki te mogą być przydatne np. do oceny stanu ucha środkowego, zwłaszcza u małych dzieci [26].

Wartość impedancji (bądź admitancji) widzianą na wejściu przewodu słuchowego zamkniętego strukturą ucha środkowego można wyznaczyć na podstawie (11) lub gdy jest już znana wartość zespolonego współczynnika odbicia $R_{\mathrm{m}}(\mathrm{j} \omega)$ (12), można, po przekształceniu wzoru (12), wyrazić ją jako:

$$
Y_{m}=\frac{1-R_{m}(j \omega)}{1+R_{m}(j \omega)} Y_{c}
$$


A

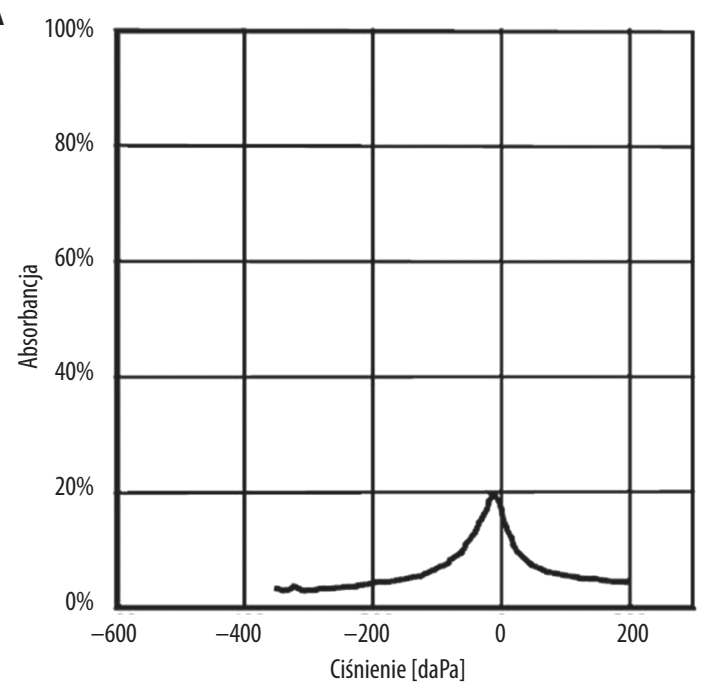

B

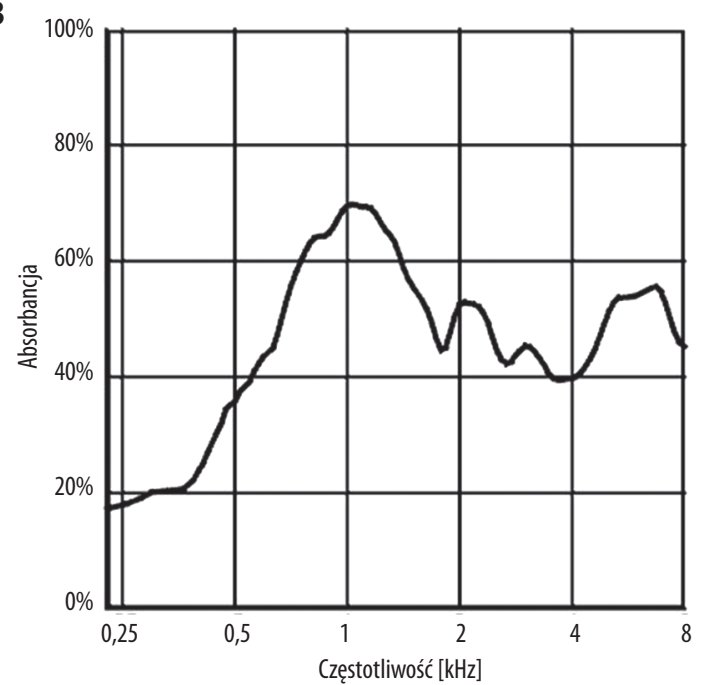

Rycina 7. Przykładowe charakterystyki absorbancji ucha normalnego. (A) „tympanogram reflektancyjny” - zależność absorbancji od ciśnienia powietrza w przewodzie słuchowym $(f=226 \mathrm{~Hz})$; (B) zależność absorbancji od częstotliwości $(P=T P)$

Figure 7. The sample characteristic of absorbance in normal ear. (A) "The reflectance tympanogram" - dependence of the absorbance on the air pressure in the ear canal $(f=226 \mathrm{~Hz}) ;(\mathbf{B})$ Dependence of the absorbance on the frequency $(P=T P)$

A

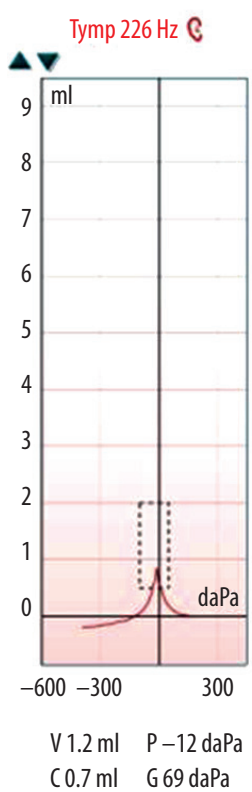

B Resonance rgequency $869 \mathrm{~Hz}$ C

\section{$\mathbf{v}$}

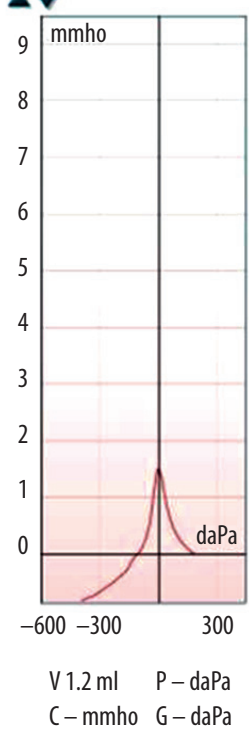

C

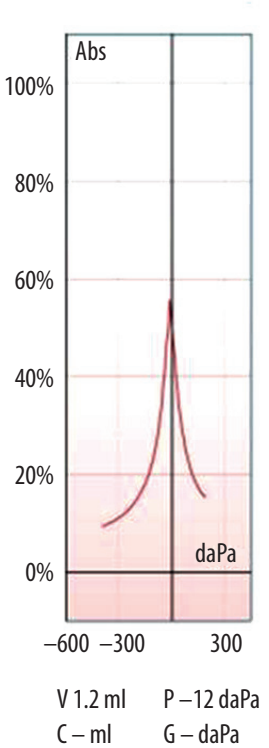

Rycina 8. Tympanogramy ucha normalnego wyznaczone na podstawie pomiarów absorbancji: (A) dla częstotliwości $226 \mathrm{~Hz}$; (B) dla częstotliwości rezonansowej $(869 \mathrm{~Hz})$; (C) tympanogram absorbancji uśrednionej w przedziale $375 \mathrm{~Hz}-2 \mathrm{kHz}$

Figure 8. Tympanograms of the normal ear determined on the basis of the absorbance measurement: (A) at $226 \mathrm{~Hz},(\mathbf{B})$ for the resonant frequency $(869 \mathrm{~Hz}),(\mathbf{C})$ tympanogram of the absorbance averaged in the interval of $375 \mathrm{~Hz}-2 \mathrm{kHz}$

gdzie $Y_{c}=1 / Z_{c}$ jest admitancją charakterystyczną przewodu słuchowego daną wzorem (1). Jak wspomniano, wartość zespolonego współczynnika odbicia $R_{\mathrm{m}}(j \omega)$, wyznaczonego w płaszczyźnie końcówki sondy pomiarowej, różni się (przesunięciem fazy) od wartości tego współczynnika w płaszczyźnie błony bębenkowej, $R_{\mathrm{t}}(j \omega)$. Różnica ta wynika z przesunięcia fazy fali akustycznej wzdłuż przewodu słuchowego:

$$
R_{t}(j \omega)=R_{m}(j \omega) e^{-2 \gamma L}
$$

gdzie $\gamma=j \omega / c$ jest zespolonym współczynnikiem falowym, a $c$ prędkością dźwięku. Jak wspomniano, długość akustyczną przewodu słuchowego zewnętrznego $L$ (średnią odległość między końcówką sondy i błoną bębenkową) można przyjąć równą $1 \div 1,5 \mathrm{~cm}$, stąd wartość różnicy fazy między $R_{\mathrm{t}}$ i $R_{\mathrm{m}}$, wynikająca ze wzoru (14), wynosi ok. $0,085 \mathrm{rad}\left(4,85^{\circ}\right)$ dla $226 \mathrm{~Hz}$ oraz ok. $0,375 \mathrm{rad}\left(21,5^{\circ}\right)$ dla $1000 \mathrm{~Hz}$. W konsekwencji wartości admitancji $Y_{\mathrm{m}}$ i $Y_{\mathrm{t}}$ różnią się co do modułu i fazy. Różnice te są znikome przy częstotliwości $226 \mathrm{~Hz}$, stosunkowo niewielkie dla $1000 \mathrm{~Hz}$, lecz mogą być istotne dla większych częstotliwości (w zakresie powyżej $1 \mathrm{kHz}$ ).

Jak stąd wynika, znajomość współczynnika odbicia pozwala wyznaczyć moduł impedancji (lub/i admitancji) przewodu słuchowego w zakresie małych częstotliwości z dokładnością nie gorszą niż w tympanometrii klasycznej. Dokładność wyznaczenia charakterystyki fazowej (oraz susceptancji) można uznać za zadowalającą w zakresie do 
co najmniej $1 \mathrm{kHz}$. Dane uzyskane z szerokopasmowego pomiaru reflektancji przy zmiennym ciśnieniu w przewodzie słuchowym pozwalają więc wyznaczyć m.in. przebieg klasycznych niskoczęstotliwościowych tympanogramów (zależności modułu admitancji akustycznej od ciśnienia). Przykłady takich tympanogramów, wyznaczonych dla osoby o słuchu normalnym, przedstawiono na rycinie 8 .

Możliwe jest oczywiście, na podstawie tych tympanogramów, wyznaczenie pozostałych parametrów charakterystycznych znanych z klasycznej tympanometrii i tympanometrii wieloczęstotliwościowej: ciśnienia szczytowego TP (odpowiadającego maksimum absorbancji lub admitancji w zakresie małych częstotliwości), podatności statycznej (wartość modułu skompensowanej admitancji $|Y t|$ dla częstotliwości $226 \mathrm{~Hz}$, podawanej zwykle jako równoważna objętość [ml]), efektywnej objętości przewodu słuchowego $-V_{\mathrm{k}}$ lub gradientu tympanogramu - G. Można także wyznaczyć częstotliwość rezonansową - $f_{\mathrm{R}}$, przyjmując, że odpowiada ona pierwszemu minimum reflektancji (maksimum absorbancji) w funkcji częstotliwości.

Metoda szerokopasmowej tympanometrii reflektancyjnej jest więc narzędziem bardzo uniwersalnym, które dostarcza zarówno danych znanych dotychczas z tympanometrii klasycznej i wieloczęstotliwościowej, jak i dodatkowych danych, istotnych dla oceny stanu narządu słuchu. Metody pomiarowe stosowane w obydwu wspomnianych metodach tympanometrii różnią się w sposób istotny, niemniej wyniki pomiarów wymienionych parametrów wykazują zadowalającą zgodność [11,27].

Wydaje się rzeczą wątpliwą, by szerokopasmowa tympanometria reflektancyjna mogła zastąpić (lub całkowicie wyprzeć) klasyczną tymapnometrię w zastosowaniach klinicznych. Niemniej, będzie na pewno cennym uzupełnieniem tej ostatniej, a znaczenie metody będzie wzrastać w miarę jej upowszechnienia.

\section{Systemy pomiarowe szerokopasmowej tympanometrii reflektancyjnej}

W chwili obecnej (2015) są dostępne na rynku dwa urządzenia do szerokopasmowej tympanometrii reflektancyjnej: system do diagnostyki audiologicznej HearID ${ }^{\infty} \mathrm{z}$ modułem MEPA (Middle Ear Power Analyzer) firmy Mimosa Acoustics $^{3}$ (rycina 9) oraz wielofunkcyjny system do badań obiektywnych słuchu Titan firmy Interacoustics ${ }^{4} \mathrm{z}$ modułem tympanometrii szerokopasmowej WBT440 (rycina 10).

Podstawę do opracowania systemu Mimosa Acoustics HearID stanowily badania prowadzone na Indiana University, Bluminton, (Boys Town National Research Hospital, Omaha, Nebraska) [5,28] i AT\&T Bell Laboratories [29]. Zespół urządzeń systemu obejmuje układ generacji i akwizycji sygnałów, dołączany jako urządzenie zewnętrzne do komputera, oryginalną sondę pomiarową ER-10C z końcówkami oraz kalibrator - wzorzec impedancji akustycznej (komplet czterech wnęk pomiarowych - rycina 9). W komputerze instalowany jest pakiet oprogramowania

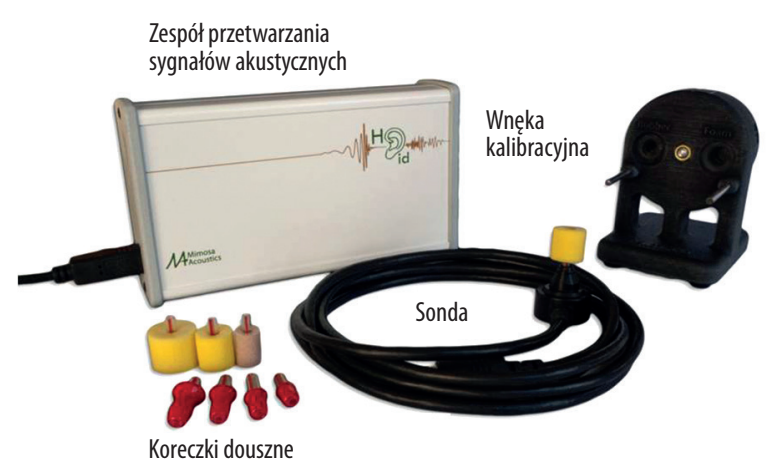

Rycina 9. Zestaw elementów składowych systemu pomiarowego Mimosa Acoustics: zespół przetwarzania sygnałów akustycznych, sonda pomiarowa z końcówkami oraz zespół wnęk kalibracyjnych (wg [35])

Figure 9. The components of the Mimosa Acoustics Middle Ear Power Analyser system: the signal processing unit, the measuring probe with ear tips and the set of calibration cavities (according to [35])

MEPA do przetwarzania, wizualizacji i archiwizacji danych pomiarowych. System pomiaru reflektancji szerokopasmowej Mimosa Acoustics jest dostępny na rynku od roku 2009, początkowo jako system przeznaczony do celów badawczych, zaś od roku 2014 posiada certyfikat FDA do diagnostyki klinicznej. Podstawową wielkością mierzoną jest reflektancja szerokopasmowa, wyznaczana w paśmie częstotliwości od 210 do $6000 \mathrm{~Hz}$ przy stałym ciśnieniu $\mathrm{w}$ przewodzie słuchowym, równym ciśnieniu otoczenia. Ucho pobudzane jest szerokopasmowym chirpem, o nominalnym poziomie $60 \mathrm{~dB}$ SPL, lecz można także stosować bodźce tonalne na kilku wybranych częstotliwościach. Zasadę pomiaru reflektancji opisano w poprzednich częściach niniejszej pracy.

Istotną cechą i zaletą systemu jest bardzo staranny proces kalibracji. Parametry schematu zastępczego Thévenina wyznacza się na podstawie pomiaru ciśnienia akustycznego w czterech wnękach, stanowiących wzorce impedancji [29]. Zaleca się, by kalibracja ta była przeprowadzana okresowo (co kilka dni lub po zmianie warunków otoczenia). Ponadto, po wprowadzeniu sondy do przewodu słuchowego wykonywana jest automatycznie tzw. kalibracja wewnętrzna, polegająca na automatycznej regulacji ciśnienia akustycznego w przewodzie słuchowym. Ponieważ system był pierwotnie przeznaczony do celów badawczych, przewidziano możliwość wyznaczenia wielu parametrów związanych z reflektancją i impedancją akustyczną. Oprócz reflektancji standardowo wyliczana jest transmitancja (poziom absorbancji w skali decybelowej) - por. rycina 3 a także m.in. wartości modułu, części rzeczywistej i urojonej impedancji i admitancji akustycznej (podawane jako wartości względne, odniesione do impedancji charakterystycznej przewodu słuchowego) oraz argument i opóźnienie grupowe współczynnika odbicia. Wybrane dane mogą być zobrazowane w postaci graficznej (wykresy) lub eksportowane $\mathrm{w}$ postaci plików numerycznych ( $\mathrm{w}$ formacie csv (Excel) lub tekstowym).

\footnotetext{
3. Mimos Acoustics Inc., 335 Fremont St., Champaign, IL 61820, USA.

4. Interacoustics A/S, Drejervaenget 8, 5610 Assens, Denmark.
} 
A

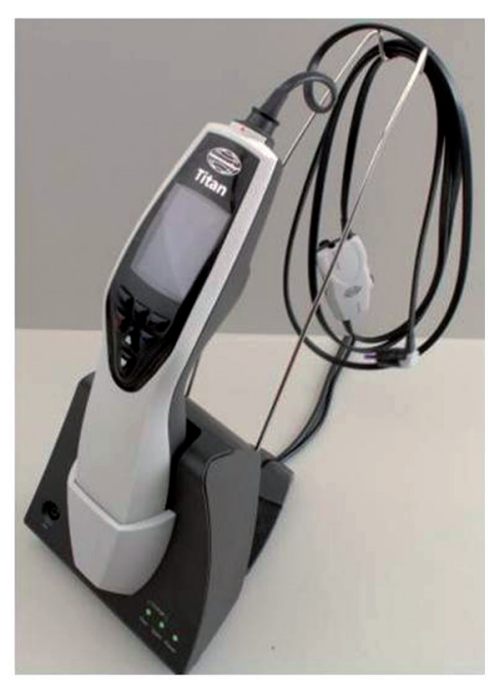

B

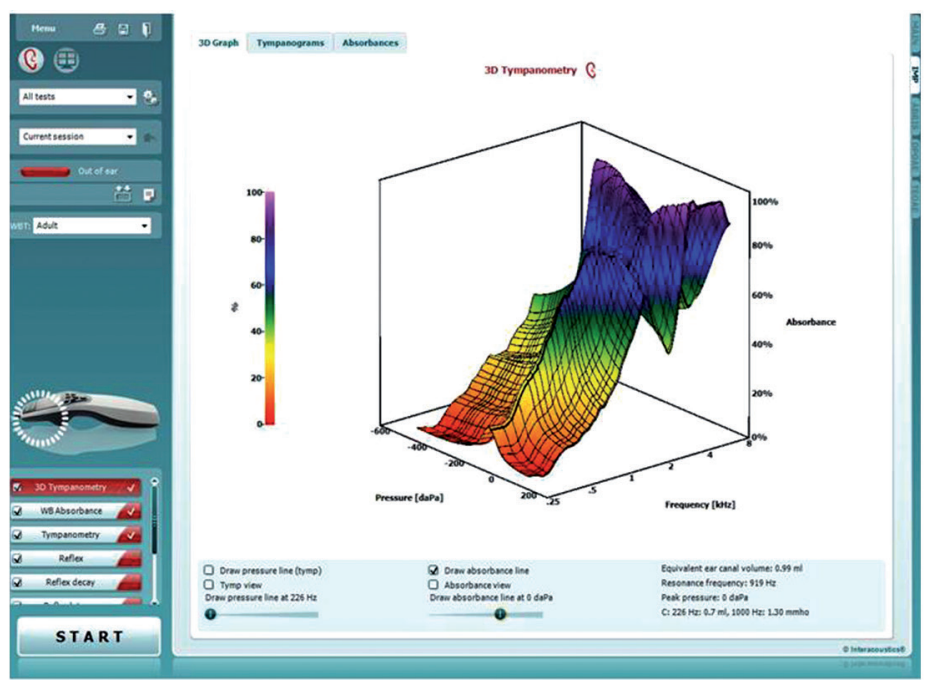

Rycina 10. System Titan do tympanometrii szerokopasmowej: (A) samodzielny zespół pomiarowy z sondą, (B) ekran programu IMP440/WBT440 (wg [34])

Figure 10. The titan with the WBT Impedance System: (A) the handheld unit with probe, (B) a screenshot from the WBT measurement with the IMP440/WBT440 software (according to [34])

Do celów diagnostycznych wykorzystuje się przede wszystkim częstotliwościową funkcję reflektancji (lub poziomu absorbancji). W polu odczytowym, gdzie wyświetlane są te wykresy, zaznaczono obszar normy, estymowany na podstawie pomiaru reprezentatywnej populacji osób otologicznie normalnych. Przebieg reflektancji wykraczający poza ten obszar może wskazywać na istnienie jednej z patologii ucha środkowego wymienionych w poprzedniej części. Pozostałe parametry mierzone, związane z impedancją akustyczną, mogą także być przydatne do oceny stanu ucha, lecz jak dotąd brak jest dokładnych danych normowych dla większości z nich (z wyjątkiem wartości modułu admitancji akustycznej dla małych częstotliwości, która odpowiada podatności statycznej mierzonej w klasycznej tympanometrii).

Zaletą systemu Mimosa HearID jest dobra precyzja i powtarzalność pomiaru, osiągana m.in. dzięki bardzo starannej kalibracji. Wniosek ten potwierdzają badania własne autorów oraz doniesienia literaturowe $[10,30]$. W systemie istnieją szerokie możliwości indywidualnego doboru ustawień: rodzaju bodźca i jego poziomu, parametrów analizy, wartości normowych i in. Złożony proces kalibracji, który przedłuża i utrudnia pomiar, stanowi pewną wadę w zastosowaniach klinicznych. Ponadto, system jest dość wrażliwy na szumy, wibracje i inne zakłócenia zewnętrzne. $\mathrm{Z}$ tego względu zalecane jest wykonanie pomiaru w kabinie audiometrycznej. Urządzenie to jest więc przede wszystkim dobrym narzędziem do celów badawczych oraz w tych zastosowaniach, gdzie zależy na wiarygodności i powtarzalności wyników.

System do audiometrii elektrofizjologicznej i impedancyjnej Interacoustics Titan z modułem do szerokopasmowej tympanometrii reflektancyjnej WBT440 (rycina 10), wprowadzony na rynek w roku 2011, został opracowany przez firmę Interacoustics na podstawie badań zespołu z Boys Town National Research Hospital $[28,24]$. Jest pierwszym dostępnym komercyjne systemem do tympanometrii reflektancyjnej, w którym pomiar parametrów reflektancyjnych (absorbancji i wielkości pochodnych) jest wykonywany w sposób automatyczny, w funkcji dwu zmiennych: częstotliwości (w zakresie od $226 \mathrm{~Hz}$ do $8 \mathrm{kHz}$ ) i ciśnienia powietrza $\mathrm{w}$ przewodzie słuchowym (typowo od ok. -300 daPa do +200 daPa). Daje to szerokie możliwości oceny różnych wielkości charakteryzujących stan ucha środkowego. W skład systemu wchodzi samodzielny zespół pomiarowy, z niezależnym zasilaniem, połączony $\mathrm{z}$ sondą, oraz komputer $\mathrm{z}$ oprogramowaniem do przetwarzania, wizualizacji i zapisu danych (rycina 10). Zespół pomiarowy zawiera układy generacji bodźców i akwizycji sygnałów oraz układy regulacji i pomiaru ciśnienia. Zastosowano bezprzewodową komunikację (łącze bluetooth) między komputerem i zespołem pomiarowym, co pozwala na wygodne posługiwanie się tym ostatnim $\mathrm{w}$ trakcie pomiaru. Bodźcem szerokopasmowym, stosowanym w pomiarach absorbancji, jest krótki impuls (trzask) o poziomie ok. $100 \mathrm{~dB}$ peSPL (ok. $65 \mathrm{~dB}$ HL), o częstotliwości powtarzania 21,5/s. System oprogramowania IMP440/WBT440 umożliwia także wykonanie klasycznych pomiarów immitancyjnych, tympanogramów na częstotliwościach $226 \mathrm{~Hz}$, $678 \mathrm{~Hz}, 800 \mathrm{~Hz}$ i $1000 \mathrm{~Hz}$ i wyznaczenie innych parametrów. Sygnałem pomiarowym jest wówczas ton o poziomie $85 \mathrm{~dB}$ SPL (ok. $69 \mathrm{~dB}$ HL dla $226 \mathrm{~Hz}$ ). Ciśnienie powietrza w przewodzie słuchowym jest zmieniane w sposób ciągły, od wartości maksymalnej do minimalnej, ze stałą prędkością (wybieraną przez użytkownika) lub automatycznie - ze zmienną prędkością, najmniejszą w pobliżu ciśnienia szczytowego. Sprawdzenie poprawności kalibracji sondy pomiarowej polega na pomiarze admitancji wnęk wzorcowych o różnych pojemnościach równoważnych $\left(0,2 ; 0,5 ; 2\right.$ i $\left.5 \mathrm{~cm}^{3}\right)$; sprowadza się to do sprawdzenia, czy zmierzona pojemność równoważna mieści się w granicach tolerancji. Nie przewiduje się kalibracji parametrów źródła sygnału (przetwornika sondy) przez użytkownika przed pomiarem (jak w systemie Mimosa), nie uwzględnia się też wpływu zmiennej średnicy przewodu słuchowego na wynik pomiaru. 
Typowy wynik pomiaru absorbancji w funkcji częstotliwości i cienienia - trójwymiarowy wykres absorbancji przedstawiono na rycinie 10B. Alternatywnie można też wyświetlić dwuwymiarowe wykresy zależności absorbancji od ciśnienia (dla wybranej częstotliwości) i absorbancji od częstotliwości (przy stałym ciśnieniu) - por. rycina 7. Wśród innych wielkości wyznaczonych z pomiaru absorbancji są m.in. klasyczne tympanogramy dla różnych częstotliwości (możliwe zobrazowanie modułu, a także susceptancji, konduktancji i argumentu admitancji). Tworzony jest również tympanogram dla częstotliwości rezonansowej (rycina 8). W postaci numerycznej dostępne są także typowe parametry tympanometryczne: równoważna objętość przewodu słuchowego, podatność statyczna (admitancja) na różnych częstotliwościach, ciśnienie szczytowe i gradient tympanogramu oraz częstotliwość rezonansowa ucha środkowego dla ciśnienia szczytowego (estymowana na podstawie pierwszego maksimum absorbancji w funkcji częstotliwości).

Jak widać, opisany system pomiarowy jest narzędziem bardzo wszechstronnym, które pozwala podczas jednego pomiaru (w czasie kilkunastu sekund) uzyskać większość danych znanych z klasycznej tympanometrii wieloczęstotliwościowej oraz daje bardzo bogatą informację o zależnościach częstotliwościowych absorbancji. Moduł do pomiarów immitancyjnych IMP440 posiada również inne funkcje związane $\mathrm{z}$ audiometrią impedancyjną, m.in. testy trąbek słuchowych, pomiary odruchu mięśnia strzemiączkowego i in.

\section{Podsumowanie i wnioski}

Metody reflektancyjnej tympanometrii szerokopasmowej, oparte na pomiarach współczynnika odbicia mocy (reflektancji), dają lepszą niż metody klasycznej tympanometrii możliwość obiektywnej oceny właściwości mechanoakustycznych ucha środkowego.

Oczekiwanym (i potwierdzonym) rezultatem jest możliwość wykrywania patologii ucha środkowego nie zawsze wykrywalnych lub nie dość dobrze diagnozowanych w klasycznej audiometrii impedancyjnej, takich jak:

- otoskleroza,

- wysiękowe zapalenie ucha środkowego,

- rozłączenie łańcucha kosteczek i in.

Szczególne znaczenie może mieć tympanometria szerokopasmowa w otolaryngologii dziecięcej [12,13,31,32], m.in. w:

- obiektywnej diagnostyce patologii ucha środkowego u małych dzieci i niemowląt,

- badaniach przesiewowych niemowląt i dzieci szkolnych.

Nie do pominięcia są korzyści naukowe wynikające ze stosowania tej metody - lepsze zrozumienie mechanizmów funkcjonowania narządu słuchu i możliwość ich modelowania.

W podsumowaniu można więc stwierdzić, że

1. Szerokopasmowa tympanometria reflektancyjna jest nową, bardzo interesującą metodą obiektywnej diagnostyki uszkodzeń narządu słuchu.
2. Metoda jest warta upowszechnienia, gdyż są już produkowane i dostępne handlowo urządzenia umożliwiające korzystanie $\mathrm{z}$ tej metody, łatwe $\mathrm{w}$ obsłudze, $\mathrm{z}$ interfejsem przyjaznym dla użytkownika.

3. Niemniej, wiele charakterystyk metody jest wciąż niedostatecznie zbadanych, a przydatność metody w praktyce klinicznej nadal wymaga weryfikacji. W szczególności dokładniejszej weryfikacji wymaga ustalenie wartości normowych (normy, które w chwili obecnej są podawane przez różnych producentów sprzętu, opierają się na badaniach stosunkowo nielicznych grup pacjentów i są częściowo rozbieżne). Weryfikacji wymaga także powtarzalność wyników pomiarów [30], zgodność wyników pomiarów wykonywanych w różnych systemach [33] i zgodność parametrów mierzonych metodą tympanometrii reflektancyjnej z tymi, jakie uzyskuje się metodami tympanometrii klasycznej [27].

Mimo wspomnianych ograniczeń, jest rzeczą bardzo celową wdrażanie metody tympanometrii reflektancyjnej do praktyki klinicznej, zwłaszcza w otolaryngologii dziecięcej. Badania wieloośrodkowe, oparte na dużym materiale klinicznym, mogą przyczynić się do rozwiania istniejących niejasności i przynieść znaczące korzyści naukowe i praktyczne.

\section{Wykaz symboli wielkości fizycznych}

$A$ - pole przekroju przewodu słuchowego

$A T F$ - poziom absorbancji (transmitancja mocy)

$B_{a}-$ susceptancja akustyczna

$B_{t}{ }^{-}-\quad$ susceptancja akustyczna ucha środkowego (wartość skompensowana)

$E_{a}-\quad$ energia fali akustycznej

EA - współczynnik pochłaniania mocy (absorbancja)

$E R$ - współczynnik odbicia mocy (reflektancjia)

$f$ - częstotliwość

$G_{a}-$ konduktancja akustyczna

$\mathrm{G}_{t}-$ konduktancja statyczna

$L$ - efektywna długość przewodu słuchowego

$P_{a}-\quad$ wartość skuteczna ciśnienia akustycznego; amplituda zespolona ciśnienia akustycznego

$P_{a m}$ - amplituda ciśnienia akustycznego

$P_{s}^{a m}-\quad$ wewnętrzne ciśnienie akustyczne źródła sygnału

$P_{m}^{s}-$ wartość mierzona ciśnienia akustycznego (w płaszczyźnie sondy)

$P_{i}-\quad$ amplituda zespolona (lub wartość skuteczna) ciśnienia akustycznego fali padającej

$P_{r}-\quad$ amplituda zespolona (lub wartość skuteczna) ciśnienia akustycznego fal odbitej

$R$ - zespolony współczynnik odbicia

$R_{m}$ - mierzony współczynnik odbicia (w płaszczyźnie sondy)

$R_{t}$ - współczynnik odbicia w płaszczyźnie błony bębenkowej

TP - ciśnienie szczytowe

$U$ - prędkość akustyczna

$U_{m}-$ amplituda prędkości akustycznej

$X_{a}^{m}-$ reaktancja akustyczna

$Y_{a}-$ admitancja akustyczna

$Y_{t}^{a}-\quad$ admitancja akustyczna ucha środkowego (wartość skompensowana)

$Y_{t m}-$ admitancja statyczna

$Z_{a}{ }^{t m}$ impedancja akustyczna 
$Z_{a m}$ - wartość mierzona impedancji akustycznej

$Z_{s}^{a m}-\quad$ wewnętrzna impedancja akustyczna źródła sygnału

$Z_{c}-$ impedancja charakterystyczna przewodu słuchowego

$\Phi$ - $\quad$ kąt fazowy admitancji akustycznej

\% - kąt fazowy impedancji akustycznej

\section{Wykaz symboli jednostek}

$[\mathrm{Pa}]$ - paskal $\left(\mathrm{N} / \mathrm{m}^{2}\right)$

[daPa] - dekapaskal $(0,1 \mathrm{~Pa})$ - jednostka ciśnienia powietrza

\section{Piśmiennictwo:}

$[\mathrm{mho}]=\left[\Omega_{a k C G S}^{-1}\right]\left(\frac{\mathrm{cm}^{3} / \mathrm{s}}{d y n a / \mathrm{cm}^{2}}\right)-\underset{\text { jednostka admitancji aku- }}{\text { stycznej w układzie CGS }}$

$\left[\Omega_{a k}\right]$ - om akustyczny - jednostka impedancji akustycznej w układzie SI

Publikacja powstała $w$ związku $z$ realizacja projektu pn. „Zintegrowany system narzędzi do diagnostyki i telerehabilitacji schorzeń narządów zmysłów (słuchu, wzroku, mowy, równowagi, smaku, powonienia)" INNOSENSE, wspólfinansowanego przez Narodowe Centrum Badań i Rozwoju w ramach Programu STRATEGMED.
1. Śliwa L, Kochanek K. Nowe metody audiometrii immitancyjnej. Cz. 1. Tympanometria klasyczna i wieloczęstotliwościowa. Now Audiofonol, 2016; 5(3): 9-21.

2. Vanhuyse V, Creten W, Van Camp K. On the W-notching of tympanograms. Scand Audiol, 1975; 4: 45-50.

3. Margolis RH, Hunter LL. Acoustic immitance measurement. W: Hosford-Dunn H, red. New York, NY: Thieme; 2000.

4. Keefe D, Bulen J, Arehart K, Burns E. Ear canal impedance and reflection coefficient in human infants and adults. J Acoust Soc Am, 1993; 94: 2617-38.

5. Withnell R, Jeng P, Waldvogel K, Morgenstein K. Allen J. An in situ calibration for hearing thresholds. J Acoust Soc Am, 2009; 125: 1605-11.

6. Rosowski JJ, Stenfelt S, Lilly D. An overview of wideband immittance measurements techniques and terminology: you say absorbance, I say reflectance. Ear Hear, 2013; 34: 9-16.

7. Feeney MP, Hunter LL, Kei j, Lilly DJ, Margolis RH, Nakajima HH i wsp. Consensus Statement: Eriksholm Workshop on Wideband Absorbance Measures of the Middle Ear. Ear Hear, 2013; 34: 78-79.

8. Keefe DH, Simmons JL. Energy transmittance predicts conductive hearing loss in older children and adults. J Acoust Soc Am, 2003; 114: 3217-38.

9. Prieve BA, Feeney MP, Stenfelt S, Shahnaz N. Prediction of conductive hearing loss using wideband acoustic immittance. Ear Hear, 2013; 34: 54-59.

10. Shahnaz N, Feeney NM, Schairer KS. Wideband acoustic immittance normative data: ethnicity, gender, aging, and instrumentation. Ear Hear, 2013; 34: 27-35.

11. Śliwa L, Kochanek K, Mazurkiewicz K, Piłka A, Skarżyński H. Evaluation of acoustic immitance measurement with wide-band tympanometry method. XXIV IERASG Symposium, Busan; 2015.

12. Hunter LL, Shanaz N. Acoustic Immitance Measures. Basic and Advanced Practice. San Diego: Plural Publishing; 2014.

13. Hunter LL, Stanford CA. Tympanometry and wideband acoustic immittance. W: Katz J, red. Handbook of Clinical Audiology. Philadelphia: Wolters Kluwer; 2015, wyd. 6, s. 137-65.

14. Nakajima HH, Rosowski JJ, Shahnaz N, Voss SE. Assessment of ear disorders using power reflectance. Ear Hear, 2013; 34: $48-53$.

15. Feeney MP, Grant IL, Marryott LP. Wideband energy reflectance measurements in adults with middle-ear disorders. J Speech Lang Hear Res, 2003; 46: 901-11.

16. Voss SE, Rosowski JJ, Merchant SN, Peake WT. Middle-ear function with tympanic-membrane perforations. I. Measurements and mechanisms. J Acoust Soc Am, 2001; 110 (3 Pt 1): 1432-44.
17. Lerut B, Pfammatter A, Moons J, Linder T. Functional correlations of tympanic membrane perforation size. Otol Neurotol, 2012; 33: 379-86.

18. Rosowski JJ, Nakajima HH, Hamade MA, Mahfoud L, Merchant GR, Halpin CF i wsp. Ear-canal reflectance, umbo velocity, and tympanometry in normal-hearing adults. Ear Hear, 2012; 33: 19-34.

19. Voss SE, Merchant GR, Horton NJ. Effects of middle-ear disorders on power reflectance measured in cadaveric ear canals. Ear Hear, 2012; 33: 195-208.

20. Allen JB, Jeng PS, Levitt H. Evaluation of human middle ear function via an acoustic power assessment. J Rehabil Res Dev, 2005; 42(4 Suppl 2): 63-78.

21. Shahnaz N, Bork K, Polka L, Longridge N, Bell D, Westerberg $\mathrm{BD}$. Energy reflectance and tympanometry in normal and otosclerotic ears. Ear Hear, 2009; 30: 219-33.

22. Zwislocki JJ. Analysis of the middle-ear function. I. Input impedance. J Acoust Soc Am, 1962; 34: 1514-23.

23. Kringlebotn M. Network model for the human middle ear. Scan Audiol, 1988; 17: 75-85.

24. Liu YW, Sanford CA, Ellison JC, Fitzpatrick DF, Gorga MP i wsp. Wideband absorbance tympanometry using pressure sweeps: System development and results on adults with normal hearing, J Acoust Soc Am, 2008; 124: 3708-19.

25. Sanford CA, Hunter LL, Feeney MP, Nakajima HH. Wideband acoustic immittance: tympanometric measures. Ear Hear, 2013; 34: 65-71.

26. Sanford CA1, Keefe DH, Liu YW, Fitzpatrick D, McCreery RW, Lewis DE i wsp. Sound-conduction effects on distortion-product otoacoustic emission screening outcomes in newborn infants: Test performance of wideband acoustic transfer functions and 1-kHz tympanometry. Ear Hear, 2009; 30: 635-52.

27. Mazurkiewicz K. Porównanie tympanometrii klasycznej z tympanometrią szerokopasmową. Dyplomowa praca magisterska, Wydział Humanistyczny Uniwersytetu Marii Curie-Skłodowskiej w Lublinie, 2015 (niepublikowana).

28. Keefe D, Levi E. Maturation of the middle and external ears: acoustic power-based responses and reflectance tympanometry. Ear Hear, 1996; 17(5): 361-73.

29. Voss S, Allen B. Measurement of acoustic impedance and reflectance in the human ear canal. J Acoust Soc Am, 1994; 95: 372-84.

30. Voss SE, Stenfelt S, Neely ST, Rosowski JJ. Factors that introduce intrasubject variability into ear-canal absorbance measurements. Ear Hear, 2013; 34: 60-64.

31. Hunter LL, Prieve BA, Kei J, Sanford CA. Pediatric applications of wideband acoustic immittance measures. Ear Hear, 2013; 34: 36-42. 
32. Kei J, Sanford CA, Prieve BA, Hunter LL. Wideband acoustic immittance measures: developmental characteristics ( 0 to 12 months). Ear Hear, 2013; 34: 17-26.

33. Michałek M. Porównanie wyników tympanometrii szerokopasmowej uzyskanych za pomocą dwóch urządzeń. Dyplomowa praca magisterska. Wydział Humanistyczny Uniwersytetu Marii Curie-Skłodowskiej w Lublinie, 2016 (niepublikowana).
34. Interacoustics Titan v.3.3. Instrukcja użycia - PL. Dostępne z URL: http://www.interacoustics.com/resources/manuals-18/ titan-manuals/832-instructions-for-use-titan-pl/file.

35. Mimosa Acoustics. MEPA3 Manual. Dostępne z URL: http:// www.mimosaacoustics.com/product.html. 